But I like to think

of that old way, the most common and slowest, the body disassembled, diffused, slowly, consumed-particle by particle, stigma, gradually, by stigma, cell by cell-converted carefully, transfigured, transformed, becoming finally both a passing grain of blue above an early evening silhouette of oaks and an inflation of sun in low October fog, both the sight of bladed wind in beach grasses and the sound of singing in the wings of desert bats, becoming as close to itself as the smooth night skin lining the skull, as the white moaning conch of its own hearing, the body becoming gradually and remarkably so indisputably so.

\title{
What the Sun God Saw One Summer Afternoon
}

Looking long enough, right before his eyes he saw the sheaths of leaf and tassel and stem split and fall, layer after layer, like transparent skins from around each stalk, until all the barley and rushes stood complete and naked, a thousand narrow blades of white fire bending and shimmering across the field.

And the smooth asters and sweet clovers, releasing their outer shells of texture and fragrance and color, became small perpetual explosions poised on their glowing stems in the dazzling roadside ditches. 
Without the bronze and violet paper

of their wings or the green of their appendicles

or the black beads of their heads, he could readily identify the dragonflies as the ignited thrum and simmer shining over the mudflats of the lowlands.

The seed shrimp, fully revealed in the pond, he saw as clear boneless stars ascending and diving among the brilliant underwater wires of fanwort and fern. And he watched the red hawk lose, without relinquishing anything, the scales and feathers and beak of its body until it circled over the meadow, a gliding bird of light alone.

How could he escape knowing then, on that afternoon, to what bovine and pepper frog and lichen-covered granite boulder had always most resolutely referred?

This was the first gift:

that he came to see everything, during the moment he saw it, as steadfastly possessing the one divine soul of his eyes. What an indispensable, what a benevolent god! to watch, to recognize, to thus create and bestow such necessary majesty. 